\title{
Antecedents Brand Trust and Private Universities Reputation
}

\author{
Nur Elfi Husda ${ }^{1}$, Tri Ratnawati ${ }^{2} \&$ Amiartuti Kusumaningtyas ${ }^{3}$ \\ ${ }^{1} \mathrm{PhD}$ Student of Economics in University of 17 Agustus 1945 Surabaya, Indonesia \\ ${ }^{2}$ Profesor in University of 17 Agustus 1945 Surabaya, Indonesia \\ ${ }^{3}$ Lecturer in University of 17 Agustus 1945 Surabaya, Indonesia \\ Correspondence: Priyono, Post Graduate Management Program, Universitas Bina Darma, Palembang, Indonesia. \\ E-mail: priyono.unu_sidoarjo@yahoo.com
}

Received: June 4, 2017

doi:10.5539/ijef.v9n8p76
Accepted: June 25, 2017

Online Published: July 10, 2017

\begin{abstract}
This study aims to analyze the brand trust and reputation of private universities from the influencing aspects of Management Information System (SIM), service quality (SERVAQUAL), customer response, Customer Relationship Management (CRM), customer value and customer satisfaction toward 360 students Management courses from 4 private universities in Riau Islands province that have used the information system as a service to students by using analytical methods that can provide a simultaneous analysis process associated with multi-variance research. The results of the research showed that SIM and SERVQUAL significantly influence consumer's response, CRM, customer value and customer satisfaction, but did not affect brand trust and University reputation.
\end{abstract}

Keywords: brand trust, reputation, private university

\section{Introduction}

According to data found in forlap.dikti.go.id the number of private universities in Indonesia today is 5,941 universities consisting of Academic, Polytechnic, Colleges, Institutes and Universities, where currently there are 998 academic-form colleges, 132 Polytechnics, 2,257 High School, 102 Institutes and 438 Universities spread throughout the Province of Indonesia. Limited seats in State Universities make Private Universities as a solution to continue the student education to a higher level. Universities need to consider the reasons a prospective student chooses a university such as distance, scholarship offered and teaching (Drewes \& Michael, 2006). Similarly, the opinion (Ming, 2010) that the decision of students to choose a college other than location, academic programs, facilities and others is the reputation of the university.

The success of colleges and universities can be seen from the extent to which they acquire new students in an efficient manner, and the ability to retain the students (Wright, 2012).The university reputation is an approach that can be used to promote universities where university with good track record will have good alumni as well (Mande, 2016). Brand is an intermediary between consumers and companies, in this study between universities and students. Consumers can develop brand trust so that consumers are loyal to the brand (Şahin, Zehir, \& Kitapçi, 2011).

This research discusses the development of theoretical model from the analysis of Management Information System, service quality, consumer response, Customer Relationship Management, customer value, and customer satisfaction as brand trust antecedent and reputation of private university in Kepulauan Riau province

\section{Literature Review}

\subsection{Management Information System}

The higher education sector will see a significant difference between past and future trends. The Information and Communication Technology Revolution will radically alter the university that led to the redefinition of the roles, needs, and expectations of students, academics and administrative staff. Using SAS ABM software will generate improved information and benefits for university administrators (Ismail, 2010). Information and Communication Technology has become a necessary tool for easily completing administrative tasks, especially in student administration and staffing, but the level of use for general administrative activities is relatively small. (Krishnaveni \& Meenakumari, 2010). 
The result of Panjaitan research, (2006) stated that there is a positive and significant direct relationship between information technology and consumer response. The use of CAF (Clicker Assessment and Feedback) or clicker technology systems by professors for formative assessment is more influential than the summative assessment of students' perceptions of involvement in learning (Han \& Finkelstein, 2013). There is a significant positive relationship between the use and perceived usefulness of the Learning Management System perceived by students (Alharbi \& Drew, 2014). The perceived convenience and benefits of using a web-based learning system on student behavior intentions in Britain and Lebanon (Tarhini, Hone, \& Liu, 2015). Libraries that provide ICT (Information and Communication Technology) facilities and e-journal subscriptions are more attractive to students as a place to study and research (Brendan, Boniface, Ezema, \& Ugwu, 2014)

Technological acceptance in the form of ease of use e-learning system and infrastructure capability significantly influence the effectiveness of E-CRM (Jafari Navimipour \& Soltani, 2016). The CRM model can improve the relationship between prospective customers (students, parents and communities) with institutions in creating emotional ties that can create two-way communication between users and providers of the academic system (Fathoni, 2014).The application of information technology significantly influences their ease and attitude towards the use of information technology education (John, 2015). Ease of use, access and reliability of the choice board system affect the satisfaction and decisions of system users (Bharati \& Chaudhury, 2006). There is a positive and significant relationship between the readiness and success of technology infrastructure and E-CRM implementation from a student perspective (Badwan et al., 2017)

Information and Communication Technology at two universities in South Africa has a significant influence on student satisfaction (Jager \& Jan, 2016). The type of interaction that is self-efficacy internet, and self-regulated in online learning is a significant predictor of student satisfaction (Kuo, Walker, Belland, \& Schroder, 2013). Effect of e-learning quality features including quality of education, service quality, technical quality of the system, and quality of content and information accompanied by e-learning ease of use significantly influence student satisfaction (Mohammadi, 2015). The use of social media applications in the learning process has a positive effect on student satisfaction (Cao, Ajjan, \& Hong, 2013). Alavinasab and Kamal (2015) state that Data security, privacy, brand name, word-of-mouth, good online experience and quality information directly affect brand trust online. So the proposed hypothesis:

H1: Management Information System significantly influence consumer response.

H2: Management Information System significantly influence to Customer Relationship Management.

H3: Management Information System significantly influence customer value.

H4: Management Information System has significant effect to customer Satisfaction.

H5: Management Information System significantly influences brand trust.

H6: Management Information System significantly affects reputation.

\subsection{Service Quality (Servqual)}

According to (Zeithaml, Bitner, \& Gremler, 2009) service quality is an evaluation focus that reflects customer perceptions about quality of service reliability, quality assurance, quality of responsibility, empathetic quality and physical quality. According to (Laksana, 2008), quality can be defined as the expected quality level and diversity control in achieving that quality to meet customer needs. Service is any action or activity which may be offered by one party to another that is essentially intangible and does not result in any ownership.

Quality services and undergraduate communication assist students in the decision-making process and will attract more students to choose university at the Technological Education Institute of Central Macedonia (TEICM) where students generally have positive opinions about the institution (Vrana, Dimitriadis, \& Karavasilis , 2015). Inadequate research where student perceptions do not meet student expectations for overall service quality at certain Higher Education in South Africa (Martinez-Arguelles \& Batalla-Busquet, 2016). Service Quality contributes to student perceptions of how departments interact as a whole (Kanakana, 2014). The dimensions of quality of education services refer academic quality, learning environment, student feedback, feedback assessment to students, and faculty which have positive and significant impact on student satisfaction (Ijaz, Irfan, Shahbaz, Cloud, \& Sabir, 2011).

Wahab, Al-Momani, and Mohd Noor, (2010) stated that E-Service Quality and ease of use have a positive and significant relationship to CRM performance.Nasution and Mavondo (2005) stated that service quality has a positive relationship with all dimensions of customer value. Quality of service perceived by students will increase productivity and service excellence become the key factor of college success (Shifa Wahab, 2016). 
SERVQUAL can find interest relative tendencies to student expectations and perceptions (Zehir, Şahin, Kitapçi, \& Özçahin, 2011).

SERVQUAL affects customer satisfaction in the service industry in which case university and tangibility have the highest influence on students' intention to continue study and spread the good news about the institution to friends and society (Mansori, Vaz, \& Ismail, 2014). SERVQUAL positively affects student satisfaction but satisfaction alone is not enough for students to recommend UPHS as a good university if the services provided are not good (Jiewanto, Laurens, \& Nelloh, 2012). SERVQUAL dimension has a positive and significant impact on student satisfaction. The quality of administrative services has a higher impact on student satisfaction than with other services. (Martinez-Arguelles \& Batalla-Busquet, 2016). So the proposed hypothesis:

H7: SERVQUAL has significant effect on consumer response.

H8: SERVQUAL significantly influence Customer Relationship Management.

H9: SERVQUAL has significant effect on customer value.

H10: SERVQUAL significantly influence customer Satisfaction.

H11: SERVQUAL significantly affects brand trust.

H12: SERVQUAL significantly affects reputation.

\subsection{Consumer Response}

Consume response is a consumer action as a result of the interaction process in consumption action where in that process there is a meeting between psychological social attributes with product attributes that produce feelings or specific actions (Assael, 2001). According to (Sangadji \& Sopiah, 2013) Consumer response is the third dimension of consumer behavior where consumer response can take the form of buying or not buying products offered by the producer / marketer.

At University a credible response is usually more reliable to guide student behavior. When trust is low, students will not feel comfortable to act to increase their confidence. Second, trust can affect the vulnerability of responses to change. (Panjaitan, 2006). The research results Río, Vázquez, and Iglesias (2001) states that consumer response is able to generate competitive advantage against the company brand. So the proposed hypothesis:

H13: Consumer response significantly affects brand trust.

H14: Consumer response significantly affects reputation.

\subsection{Customer Relationship Management (CRM)}

According to Buttle, (2007) Customer Relationship Management (CRM) is basically the main focus is to develop a customer-oriented business culture. Customer Relationship Management by Kotler and Keller, (2008) is the process of managing detailed information about each customer and carefully managing all the "touch points" of customers in order to maximize customer loyalty. Meanwhile, according to Utami, (2010) CRM is an interactive process that transforms customer data into customer loyalty through several activities: collecting customer data, analyzing customer data and identifying customer target, developing CRM program and implementing CRM program.

The benefits of implementing CRM in university environments and viewing students as customers will provide a competitive advantage and enhance the ability of universities to attract, retain and serve their students (Seeman \& O'Hara, 2006). Direct marketing to customers using information technology has different potentials in attracting more students at cost-effective and increasing accuracy and control where all recruitment is managed (Tapp, Hicks, \& Stone, 2004). The concept of "customer" in CRM should not be restricted to the business context, but is open to nonprofit contexts such as universities in this case students so that university can monitor and evaluate student needs.

Rahmadewi, Farida, and Dewi, (2015) stated that Customer Relationship Management and customer experience partially or simultaneously affect brand trust and repurchase decision. Based on the results of the test show the variables brand trust is an intervening variable to the variable purchase decision in this study. Meanwhile, according to Kim, and Kang, (2008) stated that Hospitals can succeed in creating brand image and equity positively if they can manage their relationship with customers (Customer relationship management). Where brand equity here is trust, satisfaction, commitment, loyalty and brand awareness.

Customer Relationship Management affects the organization's reputation, Customer Relationship Management and can also empower stakeholders Batista Company (2003). There is a positive influence on the implementation 
of customer relationship (CRM) on the reputation of the bank Jabar where the findings from the test results of CRM variables are Acquisition, Retail and Partnership. The partnership variable has the highest effect on the bank's reputation and the second is acquisition. Faritzal (2010).

H15: CRM has significant effect on brand trust.

H16: CRM has a significant effect on reputation.

\subsection{Customer Value}

According to Zeithaml et al. (2009) customer value is the overall assessment of the customer about the usefulness of a product or service based on the perception of what is received and what is given. Meanwhile, according to Flint, Woodruff, and Fisher Gardial (2002) customer value provides an overview of a company's customers, what customers want, and customers believe to obtain a product or service.

Customer value is a perceived quality of customer that is adjusted to the relative price of a product produced by a company (Slater \& Narver, 1994). With customer value or customer can relate the emotional bond formed between customer and producer after customer use an important product or service produced by the manufacturer and find the product that can provide an additional value. (Too, Souchon, \& Thirkell, 2001) see the need for cross-functional in a company, namely marketing, operations and human resources as a prerequisite in managing customer value.The more positive the students' perceptions of the university's market orientation the more likely they will recommend the university to their friends (Casidy, 2014)

The university strategy of attracting and retaining students as customers will produce loyal ambassadors and demonstrate good advocacy intentions. The students have a very positive perception when they see the professional appearance of staff and when they see their personal information is handled safely. (Le Roux \& Van Rensburg, 2014) Universities in increasing the number of students each year must regularly monitor the extent to which service performance, student satisfaction and their beliefs and student behavior intentions can in turn improve university brand performance and improve marketing at the University (Sultan \& Wong, 2013) Assessment of the quality of educational services is required to provide feedback to students (Shah, 2013) The student's decision to apply depends on services related to supporting facilities and infrastructure (Prakash \& Muhammed, 2016).

Hanzaee and Andervazh (2012) states that Utilitarian Value and hedonic value of a product for consumers have a positive relationship with brand trust. While Nadi and Ghahremani, (2011) stated that the Purchase Value is the total purchase of a certain transaction value based on the valuation of the buyer and of what is received (the benefits given by the given transaction have a positive effect on brand trust. The need for a minimum study period, entry requirements, teaching materials interpreted by students as a factor that can be avoided from the trap "Certificate Factory".

The importance of these factors is because e-education does not involve direct contact with institutions and staff which means brand trusts can reduce those risks (Chung, Fam, \& Holdsworth, 2012). (Jouzaryan, Ghobeyshavi, $\&$ Karimiankakolaki, 2015) states that customer value and brand affiliations have a positive effect on reputation. The proposed hypothesis:

H17: customer value significantly affects brand trust.

H18: customer value significantly affects reputation.

\subsection{Customer Satisfaction}

According to Kotler and Keller, (2008) satisfaction is the feeling of pleasure or disappointment of someone who arises because it compares the perceived performance of the product (or outcome) to their expectations. Meanwhile, according to Zeithaml et al., 2009) satisfaction is the response of customers regarding the fulfillment of needs. Lovelock, Wirtz, and Mussry, (2011) describes consumer satisfaction as a short-term consumer emotional reaction to the performance of a particular service. So it can be concluded that service performance is much lower than consumer expectations then consumers will feel dissatisfied. Consumers will feel satisfied if the performance of the service in accordance or exceed customer expectations.

The development and application of satisfaction scales as a self-assessment tool can be undertaken by universities in promoting the quality of teaching services and other sustainable improvements (Liu, Wang, \& Wu, 2017) Service quality plays a key role in predicting student satisfaction and further shaping the objectives of their behavior (Prakash \& Muhammed, 2016). By improving the quality of service, potentially increasing student satisfaction and becoming a private college priority due to the fact that they must compete for student attention to study there (Fitri \& Hasan, 2008) Student satisfaction is one of the sources of university brand success in the 
market, the arena of satisfaction will increase market share (Sultan \& Wong, 2013).

Bahari (2016) concludes that there is a significant positive effect of customer satisfaction on brand trust, customer satisfaction with brand loyalty and brand trust towards brand loyalty. From (Maghzi, Abbaspour, Eskandarian, Bakar, \& Hamid, 2011) stating that service quality and customer satisfaction have a positive influence on brand trust. Gul (2014) stated that reputation enhancement, customer satisfaction and trust will improve customer loyalty. Data analysis used in this study is regression analysis. Bontis, Booker, and Serenko (2007) stated that customer satisfaction improves reputation in the service environment. The proposed hypothesis:

H19: customer satisfaction significantly affects brand trust.

H20: customer satisfaction significantly affects reputation.

\subsection{Brand Trust}

Trust is the foundation of business. A business transaction between two or more parties will occur if each trusts each other. This trust will not simply be acknowledged by other parties / business partners, but must be built from the beginning and can be proven. Trust has been considered as a catalyst in various transactions between sellers and buyers to make customer satisfaction possible as expected (Yousafzai, Pallister, \& Foxall, 2003).

According to Delgado-Ballester and Munuera-Alemán (2005) Brand trust is a high expectation or likelihood that the brand will result in a positive outcome to the customer. Students consider that Brand University is their success rate in getting a job and salary level after graduation (Sultan \& Wong, 2013). The touch point prior to student acceptance needs to be enhanced through effective communication in the media, especially at the social media level, where the use of alumni and students to spread brand value with a major emphasis on campus placement and infrastructure can build positive perceptions and expectations about Education brands (Khanna, Jacob, \& Yadav, 2014). In developing the university brand the most important dimension is equity brand, followed by the university's reputation and emotional environment, brand loyalty and brand awareness dimensions to create a strong university brand (Pinar, Trapp, Girard, \& E. Boyt, 2014).

\subsection{Reputation}

Institutional reputation is a valuable asset that must be maintained. A reputation-keeping effort can be made when an institution understands the media's publicity to their institution. Various methods can be used by an institution to view their publicity (Prajarto, 2008). Meanwhile, according to Beheshtifar and Korouki, (2012) Reputation is a set of shared beliefs about the company's ability to meet the interests of various stakeholders.

Reputation has a positive effect on student commitment to university where university with high reputation and trusted will increase student commitment (Nguyen, Yu, Melewar, \& Hemsley-Brown, 2016).Internationalization positively affects the reputation of a university (Delgado-Marquez, Escudero-Torres, \& Hurtado-Torres, 2013)The reputation of a self-funded college institution may not only arena student satisfaction but also the arena of student loyalty also play an important role in building reputation (A. Wong, 2016). The majority of secondary schools in Hong Kong choose Universities or institutions based on brand name and reputation (J. W.-Y. Wong, Tong, \& Wong, 2014)

\section{Research Method}

This study was conducted on private university students in Riau Islands Province who have used Academic Information System and have web on the Internet as supporting in service to students. Sample criterion is a student of Management program that has accreditation of study program B because with consideration of respondent already understood about the information system and uniformity of accreditation at every university. The number of samples is proportionally distributed in each location, namely Batam University (28 samples), Putera Batam University (174 Samples), International University of Batam (91 samples), and Universitas Riau Islands (67 samples).

The research model can be seen in Figure 1. 


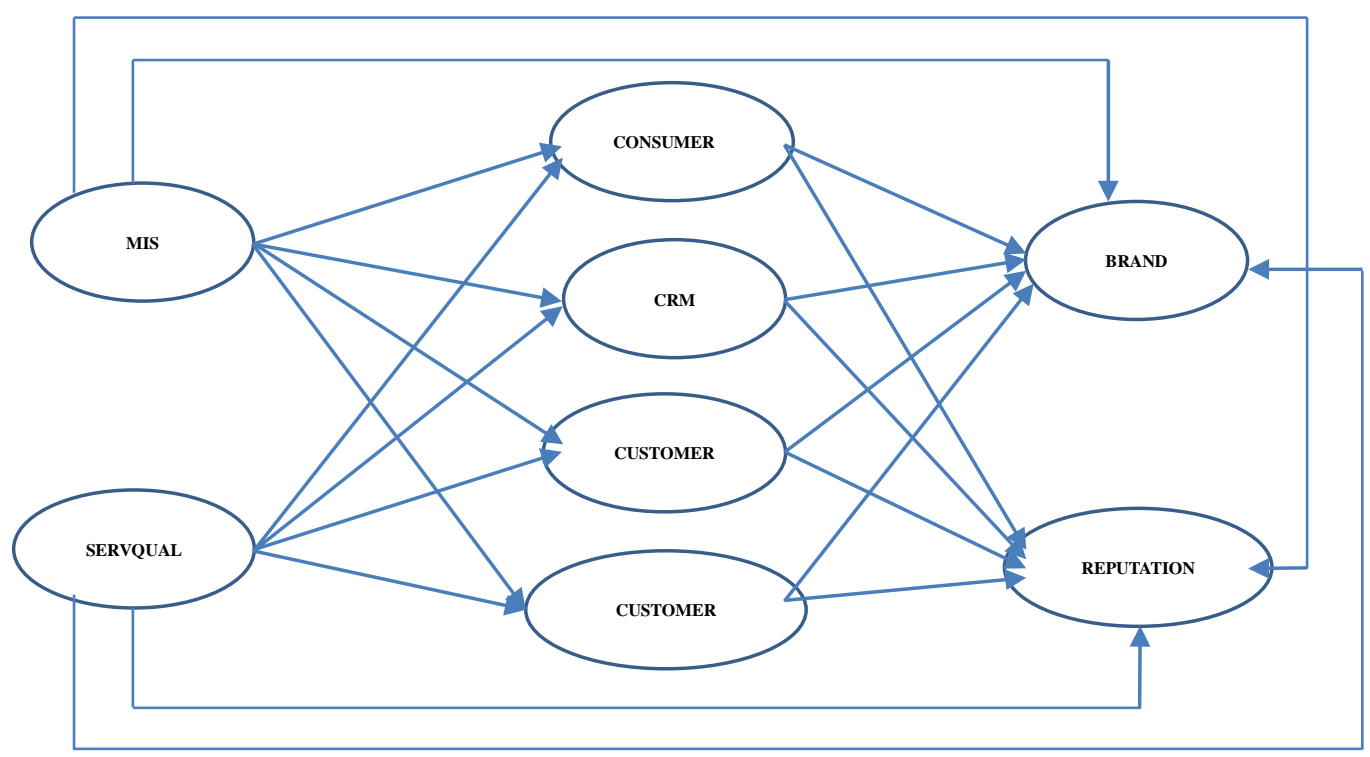

Figure 1. Research model

\section{Analysis and Discussion}

\subsection{Validity and Reliability Test Results}

The result of validity test shows significant for all indicators or items of question, which means the indicators or question items for each variable contained in the questionnaire has fulfilled the validity requirement. From the Pearson product moment correlation, it is known that all question items in the questionnaire have a significant correlation at the error rate of $5 \%(* *<0.05)$, so it can be said that all question items are valid and can be further processed.

The results of the test of reliability with Cronbach alpha $(\alpha)$ test in this study showed that all research variables are valid and realiable, because all the coefficient alpha value of each research variable is bigger than standardized (0.6), so that each question item on Measurement instruments can be used.

Test Data Normality Normal distribution of data is evaluated by skewness and kurtosis, variables that have skewness coefficient and kurtosis, variables with skewness and kurtosis coefficients with a critical ratio of no more than \pm 2.58 indicating abnormal distribution, and otherwise normal (Ferdinand, 2010). From the test known all the manifest variables that amounted to 38 items of questions has a critical ratio below \pm 2.58 , so otherwise normal.

Table 1. Estimated final parameters model

\begin{tabular}{|c|c|c|c|c|c|c|c|}
\hline \multicolumn{3}{|c|}{ Regression Weight } & \multirow{2}{*}{$\begin{array}{c}\text { Estimate } \\
, 417\end{array}$} & \multirow{2}{*}{$\frac{\text { S.E. }}{065}$} & \multirow{2}{*}{$\frac{\text { C.R. }}{6,416}$} & \multirow{2}{*}{$\frac{\mathbf{P}}{* * *}$} & \multirow{2}{*}{$\frac{\text { Standarized Estimate }}{, 425}$} \\
\hline Respon & $<--$ & SIM & & & & & \\
\hline CSR & $<---$ & SIM &, 341 & 065 & 5,227 & $* * *$ & ,334 \\
\hline Value & $<---$ & SIM &, 307 & ,066 & 4,655 & $* * *$ &, 320 \\
\hline Satifaction & $<--$ & SIM &, 416 & 073 & 5,738 & $* * *$ &, 368 \\
\hline Respon & $<---$ & servqual &, 280 & ,058 & 4,795 & $* * *$ &, 302 \\
\hline CSR & $<---$ & servqual &, 395 & ,063 & 6,320 & $* * *$ & ,409 \\
\hline Value & $<---$ & servqual &, 321 & ,062 & 5,195 & $* * *$ &, 353 \\
\hline Satifaction & $<---$ & servqual &, 324 & ,067 & 4,837 & $* * *$ &, 303 \\
\hline BrandTrust & $<--$ & Respon &,- 030 & 086 &,- 354 & ,723 &,- 027 \\
\hline Reputasi & $<---$ & Respon &, 071 & ,089 & ,790 & ,430 &, 060 \\
\hline BrandTrust & $<---$ & CSR &, 169 & 083 & 2,044 & 041 &, 156 \\
\hline Reputation & $<---$ & CSR &, 074 & ,084 &, 885 & ,376 & ,066 \\
\hline BrandTrust & $<--$ & Value & ,491 & 096 & 5,144 & $* * *$ & ,426 \\
\hline
\end{tabular}




\begin{tabular}{lllccccc}
\hline \multicolumn{2}{l}{ Regression Weight } & & Estimate & S.E. & C.R. & P & Standarized Estimate \\
\hline Reputation & $<---$ & Value &, 307 &, 095 & 3,211 &, 001 &, 256 \\
Reputation & $<---$ & Satifaction &, 238 &, 070 & 3,392 & $* * *$ &, 234 \\
BrandTrust & $<--$ & Satifaction &, 132 &, 067 & 1,968 &, 049 &, 135 \\
BrandTrust & $<---$ & SIM &,- 110 &, 085 & $-1,300$ &, 194 &,- 100 \\
Reputation & $<---$ & SIM &, 030 &, 086 &, 353 &, 724 &, 026 \\
BrandTrust & $<---$ & servqual &, 122 &, 076 & 1,602 &, 109 &, 116 \\
Reputation & $<---$ & servqual &, 124 &, 076 & 1,629 &, 103 &, 114 \\
\hline
\end{tabular}

The result after modification of the index to the model is good where the probability value above 0.05 is 0.061 as well as the RMSEA, GFI, AGFI, CMIN / DF, TLI and CFI values, all of which are spanned the expected value so that the model is acceptable.

\section{Result}

The amount of path coefficient between Management Information System variables with consumer response is 0.425 with the value of Critical Ratio $(\mathrm{CR})=6.416$ and the probability value of 0.000 . The coefficient value of 0.425 or $42.5 \%$ indicates that the variable of Management Information System influences consumer response variable of private universities in Riau Islands Province by $42.5 \%$. The probability value of 0.000 which is smaller than 0.05 indicates that the effect of Management Information System on consumer response is significant or reliable. While the beta positive value explains that the effect is unidirectional. It means the success of private universities which already have a quality Management Information System will get a good response from students, and vice versa, poor Management Information System will not get a good response from students. While the direct influence of Management Information Systems on consumer response is 0.422 which means the better Management Information System will be the better response given by consumers in this case the college student.

Data from Table 1 shows that there is a significant influence between the variables Management Information Systems to consumer response, CRM, customer value, and customer satisfaction. SERVQUAL to consumer response, CRM, customer value, and customer satisfaction, CRM to brand trust, customer value to brand trust, customer value to reputation, customer satisfaction to brand trust, customer satisfaction to reputation there is no significant influence between consumer response variable to brand trust, as well as consumer response to reputation, CRM has no effect on reputation, Management Information System has no effect on brand trust, Information System has no effect on reputation, SERVQUAL has no effect on brand trust and SERVQUAL has no effect on reputation.

The existence of findings on the role of consumer response, Customer Relationship Management, customer value and customer satisfaction on the influence of Management Information Systems and service quality to brand trust and reputation strengthen the conception of the need to consider these variables in implementing the Information Management System and Service Quality on Brand Trust because directly Management Information System and service quality have no direct effect to brand trust and reputation. This provides a gap for further development of theory around Management Information Systems, service quality, brand trust and reputation.

\section{Conclusion}

From the results of analysis and testing of hypotheses that have been done before so this research can be concluded that the Management Information System and Service Quality significantly influence the consumer response, Customer Relationship Management, customer value, customer satisfaction in the sense of success of private universities that already have Information Systems Quality management will get good responses from students, can retain existing customers, further improve customer ratings of private colleges, and make customers more satisfied. Service Quality influences consumer response, Customer Relationship Management.

While consumer responses do not significantly affect brand trust and reputation in the sense that a good consumer response does not affect the customer's confidence in the brand or high reputation. Customer Relationship Management significantly affects brand trust in the sense that better relationship management will further enhance customer confidence in the brand. But not for reputation because regardless of the value of Customer Relationship Management will not affect the high value of reputation. Customer value affects brand trust and reputation significantly in the sense that the better the value of the consumer will increase the customer's trust in the brand as well as the reputation. Customer satisfaction significantly affects brand trust and 
reputation in a sense that the more satisfied customers will increasingly increase customer confidence in brand and reputation. Similarly, Management Information Systems and service quality significantly do not significantly affect brand trust and reputation in any sense the value of the Management Information System will not affect the high level of customer trust in the brand as well as the reputation.

\section{Implications}

The result of this research that Quality Management Information System can improve the good response from consumers, maintain good relationship with customers and can maintain existing customers, improve customer ratings, and can make customers satisfied. Good service quality will improve the customer's good response and it can also improve customer relationships in order to retain customers, improve customer ratings and make customers more satisfied. The better the customer relationship management a company has, it will increase the brand trust. The better a customer's value applied, it will increase the customer's confidence in the brand as well as further enhance the reputation. The more customers satisfied, it will further increase customer confidence in the brand, and reputation.

The existence of findings about the role of intervening consumer response, Customer Relationship Management, customer value and customer satisfaction on the influence of Management Information Systems and service quality to brand trust and reputation reinforce the conception that it needs for considerations to put intervening variables in implementing Management Information System and Service Quality Against Brand trust because directly Management Information System and service quality have no direct effect to brand trust and reputation. This provides a gap for further development of theories around Management Information Systems, service quality, brand trust and reputation mainly by exploring deeper and more varied studies of intervening variables which has not found yet in this study and previous research.

\section{References}

Alavinasab \& Kamal. (2015). Studying the Influencing Factors on Online Brand Trust. International Journal of Economy, (4), 41-46.

Alharbi, S., \& Drew, S. (2014). Using the Technology Acceptance Model in Understanding Academics' Behavioural Intention to Use Learning Management Systems. International Journal of Advanced Computer Science and Applications(IJACSA), 5(1), 143-155.

Assael, H. (2001). Consumer Behavior (6th ed.). New York: Thomson Learning.

Badwan, J. J., Shobaki, M. J. Al, Naser, S. S. A., Abu, Y. M., Badwan, J. J., Shobaki, M. J. Al, .. Adopt, Y. M. A. A. (2017). Adopting Technology for Customer Relationship Management in Higher Educational Institutions To cite this version: Adopting Technology for Customer Relationship Management in Higher Educational Institutions.

Bahari, C. B. (2016). Determinants of customer loyalty: Empirical study of Semen Gresik brand. International Business Management, 10(3), 270-276. https://doi.org/10.3923/ibm.2016.270.276

Batista, L. (2003). Potentialities of customer relationship management in the building of government reputation. In Proceedings of the 3rd European Conference on E-Government (pp. 1-11).

Beheshtifar, M., \& Korouki, A. (2012). Reputation: An Important Component of Corporations' Value. International Journal of Academic Research in Business and Social Sciences, 3(7), 15-20. https://doi.org/10.6007/IJARBSS/v3-i7/6

Bharati, P., \& Chaudhury, A. (2006). Product Customization on the Web: An Empirical Study of Factors Impacting Choiceboard User Satisfaction. Information Resources Management Journal, 19(2), 69-81.

Bontis, N., Booker, L. D., \& Serenko, A. (2007). The mediating effect of organizational reputation on customer loyalty and service recommendation in the banking industry. Management Decision, 45(9), 1426-1445. https://doi.org/10.1108/00251740710828681

Brendan, A., Boniface, A., Ezema, J., \& Ugwu, C. (2014). Use of ServQUAL in the Evaluation of Service Quality of Academic Libraries in Developing Countries. Library Philosophy and Practice, 1-25.

Buttle, F. (2007). Custumer Relationship Management (Manajemen Hubungan Pelanggan). Jakarta: Bayumedia.

Cao, Y., Ajjan, H., \& Hong, P. (2013). Using social media applications for educational outcomes in college teaching: A structural equation analysis. British Journal of Educational Technology, 44(4), 581-593. https://doi.org/10.1111/bjet.12066

Casidy, R. (2014). The role of perceived market orientation in the higher education sector. Australasian 
Marketing Journal (AMJ), 22(2), 155-163. https://doi.org/10.1016/j.ausmj.2014.02.001

Chung, K., Fam, K., \& Holdsworth, D. (2012). Antecedent of Brand Trust in Online Tertiary Education: an Asian Perspective. Journal of Global Scholars of Marketing Science, 22(1), 24-44.

Delgado-Ballester, E., \& Munuera-Alemán, J. L. (2005). Does brand trust matter to brand equity? Journal of Product \& Brand Management, 14(3), 187-196. https://doi.org/10.1108/10610420510601058

Delgado-Marquez, B. L., Escudero-Torres, M. A., \& Hurtado-Torres, N. E. (2013). Being highly internationalised strengthens your reputation: An empirical investigation of top higher education institutions. Higher Education, 66(5), 619-633. https://doi.org/10.1007/s10734-013-9626-8

Drewes, T., \& Michael, C. (2006). How do students choose a university?: An analysis of applications to universities in Ontario, Canada. Research in Higher Education, 47(7), 781-800. https://doi.org/10.1007/s11162-006-9015-6

Faritzal, A. (2010). The Implementation of Customer Relationship Management ( CRM ) on a Local Regional Government Bank at West Java, (317).

Fathoni. (2014). The Development Model for Customer Relationship Management ( CRM ) to Improve The Quality of Services in Academic Information Systems Faculty of Computer Science Sriwijaya University. In Conference, International Science, Computer (pp. 125-130).

Ferdinand, A. (2010). Structural Equation Modelling (SEM) dalam Penelitian Manajemen. Semarang: Fakultas Ekonomi Universitas Diponegoro.

Fitri, H., \& Hasan, A. (2008). Service Quality and Student Satisfaction: A Case Study at Private Higher Education Institutions. International Business Research, 1(3), 163-175. https://doi.org/10.5539/ibr.v1n3p163

Flint, D. J., Woodruff, R. B., \& Fisher Gardial, S. (2002). Exploring the Phenomenon of Customers' Desired Value Change in a Business-to-Business Context. Journal of Marketing, 66(October), 102-117. https://doi.org/10.1509/jmkg.66.4.102.18517

Han, J. H., \& Finkelstein, A. (2013). Understanding the effects of professors' pedagogical development with Clicker Assessment and Feedback technologies and the impact on students' engagement and learning in higher education. Computers and Education, 65, 64-76. https://doi.org/10.1016/j.compedu.2013.02.002

Hanzaee, K. H., \& Andervazh, L. (2012). An analysis of some moderating variables on the value, brand trust and brand loyalty chain. Research Journal of Applied Sciences, Engineering and Technology, 4(10), 1403-1413.

Ijaz, A., Irfan, S. M., Shahbaz, S., Awan, M., \& Sabir, M. (2011). An Empirical Model of student satisfaction: Case of Pakistani Public Sector Business Schools. Journal of Quality and Technology Management, VII(Ii), 91-116.

Ismail, N. A. (2010). Activity-based management system implementation in higher education institution: Benefits and challenges. Campus-Wide Information Systems, 27(1), 40-52. https://doi.org/10.1108/10650741011011273

Jafari Navimipour, N., \& Soltani, Z. (2016). The impact of cost, technology acceptance and employees' satisfaction on the effectiveness of the electronic customer relationship management systems. Computers in Human Behavior, 55, 1052-1066. https://doi.org/10.1016/j.chb.2015.10.036

Jager, J. W. De, \& Jan, M. T. (2016). A Structural Equation Modelling Approach To Investigating the Impact of Academic, Ict and Management Related Factors on Customer Для Визначення Впливу Академічних. Управлінських Та Ікт-Факторів На Задоволеність Клієнтів, (Мау), 358-369.

Jiewanto, A., Laurens, C., \& Nelloh, L. (2012). Influence of Service Quality, University Image, and Student Satisfaction toward WOM Intention: A Case Study on Universitas Pelita Harapan Surabaya. Procedia Social and Behavioral Sciences, 40, 16-23. https://doi.org/10.1016/j.sbspro.2012.03.155

John, S. P. (2015). The integration of information technology in higher education: A study of faculty's attitude towards IT adoption in the teaching process, 60, 230-252.

Jouzaryan, F., Ghobeyshavi, H., \& Karimiankakolaki, M. (2015). Role of Customer Value on the Company â $€^{\mathrm{TM}}$ s Reputation Mediating Behavioral Loyalty. Case Study: Refeh Bank. International Journal of Review in Life Sciences, 5(10), 32-42.

Kanakana, M. G. (2014). Assessing Service Quality in Higher Education using the SERVQUAL Tool. 
Proceedings of the 2014 International Conference on Industrial Engineering and Operations Management Bali, Indonesia (pp. 68-74).

Khanna, M., Jacob, I., \& Yadav, N. (2014). Identifying and analyzing touchpoints for building a higher education brand. Journal of Marketing for Higher Education, 24(1), 122-143. https://doi.org/10.1080/08841241.2014.920460

Kim, K. H., Kim, K. S., Kim, D. Y., Kim, J. H., \& Kang, S. H. (2008). Brand equity in hospital marketing. Journal of Business Research, 61(1), 75-82. https://doi.org/10.1016/j.jbusres.2006.05.010

Kotler, P., \& Keller, L. K. (2008). Manajemen Pemasaran (Edisi Kedua Belas). Jakarta: PT. Indeks.

Krishnaveni, R., \& Meenakumari, J. (2010). Usage of ICT for Information Administration in Higher education Institutions - A study. International Journal of Environmental Science and Development, 1(3), 282-286. https://doi.org/10.7763/IJESD.2010.V1.55

Kuo, Y. C., Walker, A. E., Belland, B. R., \& Schroder, K. E. E. (2013). A predictive study of student satisfaction in online education programs. The International Review of Research in Open and Distributed Learning, 14(1), 16-39. https://doi.org/10.1016/j.iheduc.2013.10.001

Laksana, F. (2008). Manajemen Pemasaran : Pendekatan Praktis. Yogyakarta: Graha Ilmu.

Le Roux, A., \& Van Rensburg, R. J. (2014). Student perceptions of customer experience in a higher education environment, 1-9. https://doi.org/10.4102/ac.v14i1.232

Liu, L., Wang, Y., \& Wu, T. (2017). Student Satisfaction Scale Development and Application for Sport Management in China. EURASIA Journal of Mathematics, Science \&, 8223(5), 1429-1444. https://doi.org/10.12973/eurasia.2017.00678a

Lovelock, C., Wirtz, J., \& Mussry, J. (2011). Pemasaran Jasa: Manusia, Teknologi, Strategi Perspektif Indonesia (Edisi Ketujuh). Jakarta: Erlangga.

Maghzi, A., Abbaspour, B., Eskandarian, M., Bakar, A., \& Hamid, A. (2011). Brand Trust in Hotel Industry : Influence of Service Quality and Customer Satisfaction. 2nd International Conference on Business, Economics and Tourism Management, 24, 42-46.

Mande, W. M. (2016). The interplay between quality movement reputation and funding on private students choice of universities in uganda. Papers.ssrn.com.

Mansori, S., Vaz, A., \& Ismail, Z. M. M. (2014). Service quality, satisfaction and student loyalty in Malaysian private education. Asian Social Science, 10(7), 57-66. https://doi.org/10.5539/ass.v10n7p57

Martinez-Arguelles, M. J., \& Batalla-Busquet, J. M. (2016). Perceived service quality and student loyalty in an online university. International Review of Research in Open and Distance Learning, 17(4), 264-279.

Ming, J. (2010). Institutional factors influencing students' college choice decision in Malaysia: A conceptual framework. International Journal of Business and Social Science, 1(3), 53-58. Retrieved from http://ijbssnet.com/journals/Vol._1_No._3_December_2010/6.pdf

Mohammadi, H. (2015). Investigating users' perspectives on e-learning: An integration of TAM and IS success model. Computers in Human Behavior, 45, 359-374. https://doi.org/10.1016/j.chb.2014.07.044

Nadi, M. A., \& Ghahremani, N. (2011). Brand value and relationship performance in business markets: A cross cultural glance of business services, 5(22), 9322-9333. https://doi.org/11.5897/AJBM11.959

Nasution, N. H., \& Mavondo, F. T. (2005). The Impact Of Service Quality On Customer Value In The Hotel Industry. In ANZMAC 2005 Conference: Tourism Marketing.

Nguyen, B., Yu, X., Melewar, T. C., \& Hemsley-Brown, J. (2016). Brand ambidexterity and commitment in higher education: An exploratory study. Journal of Business Research, 69(8), 3105-3112. https://doi.org/10.1016/j.jbusres.2016.01.026

Panjaitan, H. (2006). Analisis Respon Konsumen Melalui Sistem Teknologi Informasi, Kualitas Layanan, dan Citra Perguruan Tinggi Swasta di Jawa Timur. Surabaya: Revka Petra Media.

Pinar, M., Trapp, P., Girard, T., \& E. Boyt, T. (2014). University brand equity: an empirical investigation of its dimensions. International Journal of Educational Management, 28(6), 616-634. https://doi.org/10.1108/IJEM-04-2013-0051

Prajarto, N. (2008). Efektivitas publisitas: menilai reputasi institusi. Jurnal Ilmu Komunikasi, 6(2), 78-84. 
Prakash, A. V., \& Muhammed, F. S. (2016). Service Quality in Higher Education: An Antecedent to Satisfaction and Behavioral Intentions. International Journal of Management and Applied Science, 2(5), 73-79.

Rahmadewi, T., Farida, N., \& Dewi, R. S. (2015). PENGARUH CRM DAN CUSTOMER EXPERIENCE TERHADAP KEPUTUSAN PEMBEIAN ULANG MELALUI BRAND TRUST PADA PT. NASMOCO PEMUDA. Jurnal Ilmu Administrasi Bisnis, 4(3).

Río, A. B. Del, Vázquez, R., \& Iglesias, V. (2001). The effects of brand associations on consumer response. Journal of Consumer Marketing, 18(5), 410-425. https://doi.org/10.1108/07363760110398808

Şahin, A., Zehir, C., \& Kitapçi, H. (2011). The effects of brand experiences, trust and satisfaction on building brand loyalty; an empirical research on global brands. Procedia - Social and Behavioral Sciences, 24, 1288-1301. https://doi.org/10.1016/j.sbspro.2011.09.143

Sangadji, E. M., \& Sopiah. (2013). Perilaku Konsumen Pendekatan Praktis. Yogyakarta: Andi Offset.

Seeman, E. D., \& O'Hara, M. (2006). Customer relationship management in higher education. Campus-Wide Information Systems, 23(1), 24-34. https://doi.org/10.1108/10650740610639714

Shah, F. T. (2013). Service Quality and Customer Satisfaction in Higher Education in Pakistan. Journal of Quality and Technology Management Volume IX, Issue II, IX(II), 73-89.

Slater, S. F., \& Narver, J. C. (1994). Market orientation, customer value, and superior performance. Business Horizons, 37(2), 22-28. https://doi.org/10.1016/0007-6813(94)90029-9

Sultan, P., \& Wong, H. Y. (2013). Antecedent and consequences of service quality in higher education context: A qualitative research approach. Quality Assurance in Education, 21(1), 70-95.

Tapp, A., Hicks, K., \& Stone, M. (2004). Direct and database marketing and customer relationship management in recruiting students for higher education. International Journal of Nonprofit and Voluntary Sector Marketing, 9(4), 335-345. https://doi.org/10.1002/nvsm.258

Tarhini, A., Hone, K., \& Liu, X. (2015). A cross-cultural examination of the impact of social, organisational and individual factors on educational technology acceptance between British and Lebanese university students. British Journal of Educational Technology, 46(4), 739-755. https://doi.org/10.1111/bjet.12169

Too, L., Souchon, A., \& Thirkell, P. (2001). Relationship marketing and customer loyalty in a retail setting: A dyadic exploration. Journal of Marketing Management, (4), 287-319. https://doi.org/10.1362/0267257012652140

Utami, C. W. (2010). Manajemen Ritel: Strategi dan Implementasi Operasional Bisnis Ritel Modern di Indonesia. Jakarta: Salemba Empat.

Vrana, V. G., Dimitriadis, S. G., \& Karavasilis, G. J. (2015). Students' perceptions of service quality at a Greek higher education institute. International Journal of Decision Sciences, Risk and Management, 6(1), 80. https://doi.org/10.1504/IJDSRM.2015.072770

Wahab, S. (2016). The Implication of Customer Service in Higher Education: Review Paper. International Journal of Education and Practice, 4(3), 106-111. https://doi.org/10.18488/journal.61/2016.4.3/61.3.106.111

Wahab, S., Al-Momani, K., \& Mohd noor, N. A. (2010). The relationship between e- service quality and ease of use on customer relationship management (CRM) performance: An empirical investigation in Jordan mobile phone services. Journal of Internet Banking and Commerce, 15(1), 1-16. https://doi.org/Article

Wong, A. (2016). Student Satisfaction and School Reputation: The Moderating Role of Student Loyalty and School Image. Journal of Marketing and HR, 2(1), 113-125.

Wong, J. W. Y., Tong, C., \& Wong, A. (2014). The influences of teaching quality, student satisfaction, school image, and student loyalty on the reputation of self-financed higher education institutions in Hong Kong, 4(December), 1557-1582.

Wright, R. E. (2012). Marketing Orientations and Higher Education: Applications and Implications. Journal of Applied Business and Economics, 13(5), 53-57.

Yousafzai, S. Y., Pallister, J. G., \& Foxall, G. R. (2003). A proposed model of e-trust for electronic banking. Technovation, 23(11), 847-860. https://doi.org/10.1016/S0166-4972(03)00130-5

Zehir, C., Şahin, A., Kitapçi, H., \& Özçahin, M. (2011). The effects of brand communication and service quality in building brand loyalty through brand trust; the empirical research on global brands. Procedia - Social and 
Behavioral Sciences, 24, 1218-1231. https://doi.org/10.1016/j.sbspro.2011.09.142

Zeithaml, V., Bitner, M. J., \& Gremler, D. (2009). Services Marketing - Integrating Customer Focus Across the Firm. New York: McGraw Hill.

\section{Copyrights}

Copyright for this article is retained by the author(s), with first publication rights granted to the journal.

This is an open-access article distributed under the terms and conditions of the Creative Commons Attribution license (http://creativecommons.org/licenses/by/4.0/). 